\title{
Leucocyte behaviour in controlled ischaemia of the calves
}

\author{
G CIUFFETTI, M MERCURI, RITA LOMBARDINI, G MARAGONI, \\ LAURA SANTAMBROGIO, E MANNARINO
}

From the Second Department of Internal Medicine, University of Perugia, Perugia, Italy

SUMMARY Whole blood filterability and leucocyte behaviour (number, activation, and subfraction filterability rates) were monitored at the earliest stage of peripheral ischaemia in 18 patients with stage II peripheral occlusive arterial disease (PAOD) and 20 matched controls. A model of controlled ischaemia, using exercise to stress leg circulation, was set up and blood samples were taken before exercise, at the onset of calf pain, and at recovery from peak exercise. Leucocytes were counted, separated into their subfractions on a Ficoll-Hypaque density gradient and by adhesion to Petri dishes, and filtered in buffer (like the whole blood suspensions) through $5 \mu \mathrm{m}$ pore diameter Nuclepore filters. Unfractionated white cells, separated under gravity, with pseudopodia or cytoplasmic irregularities were regarded as activated. The whole blood filterability rate was significantly increased at the onset of calf pain and was associated with significant increases in the number of leucocytes and in the filterability rate of the monocyte sutifraction, the latter persisting throughout the recovery period. No significant changes were observed in the other variables monitored, showing that impairments in white cell rheology may be associated with ischaemia.

The plasma fibrinogen concentration,' red blood cell, ${ }^{23}$ white ${ }^{4}$ cell rheology, the number of leucocytes ${ }^{5}$ and leucocyte activation ${ }^{67}$ determine the flow resistance of blood in the microcirculation and hence whole blood filterability. ${ }^{8}$ Because this is impaired when ischaemia occurs, ${ }^{8}$ several recent studies have attempted to define the individual contributions of these factors under ischaemia conditions. Plasma viscosity does not, for example, significantly increase when calf pain occurs in patients with peripheral occlusive arterial disease (POAD) ${ }^{9}$; the erythrocytes make a limited contribution to the onset and development of tissue ischaemia. ${ }^{10}$ The focus of attention has consequently shifted to leucocytes. Impairments in their rheological properties, ${ }^{6}$ modifications in their number, ${ }^{5}$ and their activation ${ }^{67}$ seem to be the major factors involved in the onset and progression of ischaemic events. $^{67}$

\section{Patients and methods}

Eighteen non-diabetic smokers with POAD (16 men and two women, age range 52-69 years, average age 63 years) were recruited from the outpatient clinic of the

Accepted for publication 2 May 1989 second department of internal medicine between February 1988 and January 1989. Criteria for selection comprised the following: (i) a minimum of two years since the clinical onset of POAD; (ii) stabilisation of POAD for at least six; (iii) the onset of calf pain at less than 200 metres (treadmill walking test); and (iv) atherosclerotic disease in the large blood vessels of both legs (Doppler velocimetry with the Windsor Index between 0.55 and 0.65 ). Three of the patients had systemic hypertension and two hypercholesterolemia. Informed consent was obtained from each patient, and the study was approved by the hospital ethics committee.

Over the same period of time a control group of 20 outpatients with no clinical evidence of vascular disease was selected. They were closely matched to patients for age (range 51-68 years; average age 62 years), sex (18 men and two women), and incidence and distribution of cardiovascular risk factors and accompanying diseases (five had systemic hypertension and three hypercholesterolemia). No significant differences between patients and controls existed in terms of body mass index and smoking habitspatients averaged 18 cigarettes a day and controls 20 .

Subjects with any severe medical or surgical problems, a recent history of infection, chronic 
alcoholism, osteoporosis, or who were unable to perform a treadmill test were excluded from the study.

None of the subjects recruited was being treated with antioxidants or drugs which could potentially interfere with leucocyte functioning. Drugs known or suspected to have an effect on the haemorheological pattern were suspected for at least 20 days before beginning the study.

Blood samples, anticoagulated with dry dipotassium edetate (EDTA $1.5 \mathrm{mg} / \mathrm{ml}$ ), were taken from the arm vein of each subject after an overnight fast, immediately before treadmill tests (rest), at peak exercise, maximum five minutes walking, $2 \mathrm{~km} /$ hour at a constant gradient of $12 \%$ (exercise), and finally when the ankle:arm pressure ratio by Doppler velocimetry (Stereodop 448-S, Ultrasomed, Milan, Italy), had recovered its initial value (recovery). The study protocol required the patients to stop exercise at the first sign of calf pain.

The following haemorheological variables were determined:

1 The total leucocyte count by automated haematolcgy analyser (Toa Medical Electronics Co Ltd, Japan);

2 The differential count of the leucocyte subpopulations - that is, granulocytes, lymphocytes, and monocytes-from 200 cells in whole blood smears stained with May-Grünwald-Giemsa and counted using a light microscope;

3 At each stage of the study unfractionated white cells were separated from $10 \mathrm{ml}$ of whole blood by sedimentation under gravity. A small proportion of the unfractionated cells was fixed in $1 \%$ glutaraldehyde for morphological examination by light microscopy and the percentage of cells with pseudopodia or cytoplasmic irregularities calculated. These nonspherical cells were classified as "active""l;

4 The filterability, after separation and suspension, of whole blood and the individual leucocyte subfractions.

SEPARATION AND PREPARATION OF SUSPENSIONS Whole blood: Whole blood was prepared for filtration by suspending it at $10 \%$ haematocrit in $2 \%$ phosphate buffered saline (PBS) (pH 7.4, osmolality $290 \mathrm{mOsm} /$ $\mathrm{Kg}$ ) (Dulbecco A; Oxoid Ltd, United Kingdom); Leucocytes: The granulocyte, monocyte, and lymphocyte cellular subpopulations were separated in two steps. The first, by density, separated the mononuclear leucocyte subpopulation from granulocytes on a Ficoll-(Pharmacia, Sweden) Hypaque (Sterling Research Ltd, United Kingdom) gradient $(1.114 \mathrm{~g} / \mathrm{ml}$ and $1.022 \mathrm{~g} / \mathrm{ml}){ }^{12}$ Mononuclear cells, obtained from another blood sample by the same technique, were separated into monocyte and lymphocyte cells by adherence to Petri dishes. ${ }^{13-15}$ The mononuclear cell subpopulation was resuspended in RPMI 1640 medium (Flow Laboratories, Italy), and supplemented with $10 \%$ fetal calf serum to bring the total concentration to $1 \times 10^{6} \mathrm{cells} / \mathrm{ml}$. This cell suspension was layered in a $55 \mathrm{~mm}$ diameter Petri dish and incubated for two hours at $37^{\circ} \mathrm{C}$ with $5 \%$ carbon dioxide. The supernate (the lymphocyte subpopulation) was removed using a Pasteur pipette.

Trypsin $(5 \mathrm{ml})$ and EDTA $0.05 \%$ were added to the adhering cells (monocytes) to help detach them from the Petri dish. After gentle shaking the monocyte cells were collected using a Pasteur pipette, washed twice in RPMI 1640 medium, resuspended in $10 \mathrm{ml}$ PBS + $0.5 \%$ bovine serum albumin (Sigma, UK), centrifuged (Beckman Model TJ-6, Milan, Italy) at 1400 rpm for 10 minutes and resuspended at a concentration of $10^{6}$ cells $/ \mathrm{ml}$. Morphological examination determined the type of subfraction which was fixed and stained on a cytospin smear using Wright-Giemsa and $\alpha$-naphtylacetate-esterase (ANAE).

As the mononuclear cell subpopulations cannot be separated without trysin, the enzyme was used on all the other cellular subfractions-the granulocyte cells, the unseparated sample of mononuclear cells, and, after adherence, the lymphocyte cells-because leaving these subfractions untreated could have created non-homogenous conditions for evaluating the rheological properties of the leucocyte subpopulations.

The variability estimated by trypan blue exclusion and was more than $98 \%$ at the end of preparation for all suspension samples.

Quality assurance was satisfactory for the separation procedure of the leucocyte subpopulations. Morphological examination on slides of cytocentrifuge cell suspensions showed that purity was more than $98 \%$ for all the leucocyte subpopulations under study. The monocyte cells obtained, as described above, were tested for cytoplasmic non-specific esterase activity and more than $97 \%$ of the harvested adherent cell population was $\alpha$-naphtyl-acetate esterase positive. The filtration measurements were carried out immediately.

\section{FILTRATION PROCEDURE}

Each suspension sample was filtered by a constant flow syringe pump (Vickers UK) $(1.5 \mathrm{ml} /$ minute for six minutes, and the pressure rise monitored by a pressure transducer (Bell and Howell UK) linked to an amplifier (Gaeltech UK) and chart recorder (Logos, Italy). The filterability rate was expressed as the final filtration pressure generated by the cell suspension relative to the buffer, previously filtered through the same filter. ${ }^{12}$ A single batch of Nuclepore membranes (Nuclepore Corporation, Pleasanton, California, USA, No $5414 \mathrm{C} 32$ ) with $5 \mu \mathrm{m}$ pore diameter was used 
for the filtrations throughout this study. Filtrations were performed at $25+/-1^{\circ} \mathrm{C}$ and measurements were completed within five hours of vein puncture.

Effect of trypsin on filterability: After treatment with trypsin the average granulocyte and mononuclear subpopulation filterability rate values (mononuclear data not included in this study) did not vary significantly (unpaired Wilcoxon sum test) from our standard filtration values for the same subpopulations. ${ }^{16-18}$ Other reports have confirmed that trypsin does not affect cell membrane structure. ${ }^{13}$

Reliability: This was confirmed by five successive filtrations of cell suspensions giving mean coefficients of variation. At the fifth filtration the mean was $2.6 \%$ for whole blood, $2.9 \%$ for granulocytes, $3 \cdot 1 \%$ for lymphocytes and finally $3.6 \%$ for monocytes.

Effect of filtration on activation: No significant differences in the percentage of "active" cells in any of these leucocyte subpopulation suspensions were observed after filtration.

Student's " $t$ " test for paired samples or, when appropriate, the Kruskal-Wallis one way analysis by ranks were used for the statistical analysis of the results: $p$ values of $<0.05$ were taken as being significant.

\section{Results}

At rest no significant differences existed in the mean values of all the variables monitored.

At peak exercise significant increases in the average values of both the whole blood and the monocyte subpopulation filterability rates were observed in the patients when compared with basal values at rest

Table 1 Filterability* rates (mean (SD))

\begin{tabular}{|c|c|c|}
\hline & $\begin{array}{l}\text { Controls } \\
(n=20)\end{array}$ & $\begin{array}{l}\text { Patients } \\
(n=18)\end{array}$ \\
\hline $\begin{array}{l}\text { Whole blood: } \\
\text { Rest } \\
\text { Exercise } \\
\text { Recovery }\end{array}$ & $\begin{array}{l}4.92(0.77) \\
4.90(0.81) \\
4.99(0.80)\end{array}$ & $\begin{array}{l}5.14(0.74) \\
7.04(0.81) \dagger \\
5.78(0.95) \ddagger\end{array}$ \\
\hline $\begin{array}{l}\text { Gramulocyte cells: } \\
\text { Rest } \\
\text { Exercise } \\
\text { Recovery }\end{array}$ & $\begin{array}{l}4.02(0.51) \\
4.14(0.58) \\
4.01(0.64)\end{array}$ & $\begin{array}{l}4.27(0.50) \\
4.64(0.76) \\
4.66(0.62)\end{array}$ \\
\hline $\begin{array}{l}\text { Lymphocyte cells: } \\
\text { Rest } \\
\text { Exercise } \\
\text { Recovery }\end{array}$ & $\begin{array}{l}4.83(0.58) \\
4.75(0.61) \\
4.68(0.49)\end{array}$ & $\begin{array}{l}4.81(0.49) \\
4.75(0.70) \\
4.80(0.47)\end{array}$ \\
\hline $\begin{array}{l}\text { Monocyte cells: } \\
\text { Rest } \\
\text { Exercise } \\
\text { Recovery }\end{array}$ & $\begin{array}{l}11.36(1.74) \\
11.41(1.57) \\
11.27(1.03)\end{array}$ & $\begin{array}{l}11.05(1.46) \\
13.37(1.71) \rrbracket \S \\
13.20(1.41) \dagger \ddagger\end{array}$ \\
\hline
\end{tabular}

*Pressure ratio of cell suspension to buffer after six minutes filtration.

tp $<0.0001$ Ip $<0.001$ compared with data taken at rest.

$\neq \mathrm{p}<0.0001 \S \mathrm{p}<0.001 v$ control group.
Table 2 White cell counts (mean (SD))

\begin{tabular}{|c|c|c|}
\hline & $\begin{array}{l}\text { Controls } \\
(n=20)\end{array}$ & $\begin{array}{l}\text { Patients } \\
(n=18)\end{array}$ \\
\hline $\begin{array}{c}\text { Total cells ( } \\
\text { Rest } \\
\text { Exercise } \\
\text { Recovery }\end{array}$ & $\begin{array}{l}7.27(1.01) \\
9.42(1.34)^{*} \\
7.29(1.05)\end{array}$ & $\begin{array}{l}6.97(1.33) \\
9.44(1.70)^{*} \\
6.98(1.31)\end{array}$ \\
\hline $\begin{array}{c}\text { Granulocyte } \\
\text { Rest } \\
\text { Exercise } \\
\text { Recovery }\end{array}$ & $\begin{array}{l}3.86(0.87) \\
4.25(0.85) \\
3.91(0.82)\end{array}$ & $\begin{array}{l}3.59(0.92) \\
4.08(0.87) \\
3.62(0.89)\end{array}$ \\
\hline $\begin{array}{c}\text { Lymphocyte } \\
\text { Rest } \\
\text { Exercise } \\
\text { Recovery }\end{array}$ & $\begin{array}{l}3.21(0.64) \\
4.74(0.70) * \\
3.17(0.67)\end{array}$ & $\begin{array}{l}3.18(0.60) \\
4.93(1.03)^{*} \\
3.16(0.54)\end{array}$ \\
\hline $\begin{array}{l}\text { Monocyte cel } \\
\text { Rest } \\
\text { Exercise } \\
\text { Recovery }\end{array}$ & $\begin{array}{l}0.20(0.15) \\
0.42(0.13)^{*} \\
0.21(0.14)\end{array}$ & $\begin{array}{l}0.20(0.14) \\
0.44(0.14)^{*} \\
0.20(0.17)\end{array}$ \\
\hline
\end{tabular}

$* p<0.0001$ compared with data taken at rest.

$(+37 \%, p<0.0001 ;+21 \%, p<0.001$, respectively) and with the control group at peak exercise $(+43 \%$, $\mathrm{p}<0.0001 ;+17 \%, \mathrm{p}<0.001$, respectively) (table 1). In both groups significant increases were recorded in the total number of leucocytes (controls $+30 \%$, $\mathrm{p}<0.0001$; patients $+35 \%, \mathrm{p}<0.0001)$, of lymphocytes (controls $+48 \%, \mathrm{p}<0.0001$; patients $+55 \%, \mathrm{p}<0.0001)$, and finally of monocytes (controls $+114 \%, p<0.0001$; patients $+115 \%$, $\mathrm{p}<0.0001)$ (table 2).

A significant increase in recovery $(p<0.0001)$ in the monocyte cell subpopulation filterability rate was observed in the patients compared with basal values at rest $(+19 \%)$ and with the controls at recovery time $(+17 \%)$ (table 1$)$.

No significant differences emerged at any stage of the study in the mean values of either the granulocyte or lymphocyte filterability rates (table 1), the granulocyte count (table 2), or in sedimented unfractionated cell activation (table 3 ).

\section{Discussion}

This study shows how a brief period of strenuous exercise increases the whole blood filterability rate in

Table 3 Leucocyte activation assay (mean ( $S D)$ )

\begin{tabular}{lll}
\hline & $\begin{array}{l}\text { Controls } \\
(n=20)\end{array}$ & $\begin{array}{l}\text { Patients } \\
(n=18)\end{array}$ \\
\hline $\begin{array}{l}\text { Activation* } \\
\text { Sedimented unfractionated cells }\end{array}$ & \\
Rest & $11 \cdot 18(3.11)$ & $11.89(2.81)$ \\
Exercise & $12.30(3.16)$ & $12.56(3.27)$ \\
Recovery & $12.70(2.68)$ & $12.89(3.45)$ \\
\hline
\end{tabular}

* = Cells with pseudopodia and or cytoplasmatic irregularities observed in suspension sample under light microscope (expressed as percentage). 
patients affected by POAD. When compared with controls matched for age, sex, body mass index, vascular risk factors and accompanying diseases, the average values of the whole blood filterability rate were significantly higher in patients. After recovery they did not return to, though they approached, basal values.

This increase was associated with pronounced modifications in leucocyte behaviour which did not, however, include activation. The lack of unfractionated white cell activation throughout the study may seem surprising as spontaneous activation is known to occur in vivo in response to tissue damage. ${ }^{19-23}$ Changes in leucocyte rheology under hypoxic conditions are not, in fact, necessarily associated with the protopod formation typical of activation. ${ }^{24}$ Unlike the clinical studies cited above, ${ }^{21} 22$ our study did not investigate white cell activation after a major ischaemic event but created conditions for taking blood samples at the earliest stage of ischaemia in patients with POAD. This may explain the lack of activation. Leucocyte cells could well, in fact, become activated at a later stage of the ischaemic process.

At the first stage of ischaemia what was observed was a significant increase after exercise in the total white cell count, associated with a shift in the white cell differential count from granulocytes to the mononuclear cells. This, however, disappeared at recovery. Because it occurred in both patients and controls we consider that it may be, to some extent, the physiological expression of the "haematological stress syndrome"25 when mononuclear cells are released from the marginal pool of adrenalin ${ }^{2627}$-and cortisol $^{28}$ - dependent leucocytes.

This study shows that the reduction in whole blood filterability is associated with the pronounced abnormality in monocyte filterability which appeared only in the patients at the onset of ischaemia of the calves and which persisted throughout the recovery period. It confirms that impairments in white cell rheology-whether due to the monocyte $e^{29}$ or polymorphonuclear $^{30}$ subfractions-may be associated with ischaemia.

In conclusion, whole blood filterability is impaired at the onset of ischaemia in patients with POAD. At its peak, this impairment is accompanied by an increase in the total leucocyte count (associated with the shift in white cell differential from granulocytes to the mononuclear cell subfraction) and a reduced monocyte filterability. Although this important impairment in the monocyte filterability persists throughout the recovery period, the increase in the leucocyte count disappears and the rate of whole blood filterability approaches basal values. This implies that at the onset of calf pain an increase in the leucocyte count and an impairment in monocyte filterability are both involved in worsening the whole blood filterability.
We thank Ms GA Boyd Mancinelli and Christian Ott for their invaluable assistance.

\section{References}

1 Kenny MW, Meakir M, Stuart J. Measurement of erythrocyte $\frac{\bar{S}}{D}$ filterability using washed-erythrocyte and whole-blood methods. Clin Hemorheol 1981;1:135-46.

2 Ehrly AM, Kohler HJ. Altered deformability of erythrocytes from patients with chronic occlusive arterial disease. Vasa $\overrightarrow{0}$ 1976;5:319-22.

3 Irwin ST, Rocks MJ, McGuigan JA, Patterson CC, Morris TCM, $\overrightarrow{\vec{\omega}}$ O'Reilly MJG. Effect of reconstructive vascular surgery on red cell deformability-preliminary results. J Clin Pathol 1983;36:1136-9.

4 Lichtman MA, Heal J, Rowe JM. Hyperleukocytic leukaemia: iv rheological and clinical features and management. Clin Haematol 1987;1:725-46.

5 Alderman MJ, Ridge A, Morley AA, Ryall RG, Walsh JA. Effect of total leucocyte count on whole blood filterability in patients with peripheral vascular disease. J Clin Pathol 1981;34:163-6. $\omega$

6 Gaehtgens P. Deformation and activation of leukocytes-two 응 contradictory phenomena? In: Meiselman HJ, Lichtman MA, LaCelle PL. eds. White cell mechanics: basic science and clinical aspects. New York: AR Liss, 1984:159-65.

7 Ernst E, Hammerschmidt DE, Bagge U, Matrai A, Dormandy JA. Leukocytes and the risk of ischaemic disease. JAMA 1987;257:2318-24.

8 Forconi S, Pieragalli D, Guerrini M, DiPerri T. Hemorheology $\vec{C}$ and peripheral arterial diseases. Clin Hemorheol 1987;7:145-58

9 Ciuffetti G, Mercuri M, Mannarino E, Robinson MK, Lennie SE Lowe GDO. Peripheral vascular disease: rheological variables. during controlled ischaemia. Circulation (in press).

10 Bareford D, Lucas GS, Caldwell NM, Stone PCW, Baar S, Stuarir J. Erythrocyte deformability in peripheral occlusive arterial disease. J Clin Pathol 1985;38:135-9.

11 Nash GB, Jones JG, Mikita J, Christopher B, Dormandy JA. Effects of preparative procedures and of cell activation on flow of white cells through micropore filters. Br J Haematol 1988;70:171-6.

12 Lennie SE, Lowe GDO, Barbenel JC, Forbes CD, Foulds WS Filterability of white blood cell subpopulations, separated by an improved method. Clin Hemorheol 1987;7:811-6.

13 Golde DW, Cline MJ. Identification of the colony-stimulating cell in human peripheral blood. J Clin Invest 1972;51:2981-3.

14 Messner HA, Till JE, McCulloch EA. Intereacting cell populations affecting granulopoietic colony function by normal and leukemic human marrow cells. Blood 1973;42:701-10.

15 Nash GB, Jones JG, Mikita J, Dormandy JA. Methods and theory for analysis of flow of white cell subpopulations Br J Haematol 1988;70:165-70.

16 Ciuffetti G, Mannarino E, Pasqualini L, et al. The haemorheological role of cellular factors in peripheral vascular disease. Vasa 1988;17:168-70.

17 Ciuffetti G, Balendra R, Lennie SE, Anderson J, Lowe GDO. Impaired white blood cell filterability in acute cerebral infarction. Br Med J 1989;298:930-1.

18 Ciuffetti G, Mercuri M, Rizzo MT, Lennie SE, Lowe GDO. Age and blood cell rheology. Gerontology 1989;35:31-5.

19 Bagge U, Amundson B, Lauritzen C. White blood cell deformability and plugging of skeletal muscle capillaries in 0 hemorragic shock. Acta Physiol Scand 1980;108:159-63.

20 Schmid-Schonbein GW, Skalak K, Sung KLP, Chien S. Human $\mathbb{E}$ leukocytes in the active state. In: Bagge U, Born GV, Gaehtgens $P$, eds. White blood cells, morphology and rheology as related in function. The Hague: Martinus Nijhoff, 1982:21-3.

21 Violi F, Rasura M, Alessandri C, et al. Leukocyte response in patients suffering from acute stroke. Stroke 1988;19:1283-4.

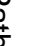


22 Nash GB, Thomas PRS, Dormandy JA. Abnormal flow properties of white blood cells in patients with severe ischaemia of the leg. Br Med J 1988;296:1699-701.

23 Harlan JM. Leukocyte-endothelian interactions. Blood 1985;65:513-25.

24 Ciuffetti G, Mercuri M, Rizzo MT, Lombardini R, Mannarino E. Human leucocyte rheology and tissue ischaemia. Eur $J$ Clin Invest (in press).

25 Stuart J, George AJ, Davies AJ, Aukland A, Hurlow RA. Haematological stress syndrome in atherosclerosis. $J$ Clin Pathol 1981;34:464-7.

26 Samuels AJ. Primary and secondary leucocyte changes following intramuscular injection of epinephrine hydrochloride. J Clin Invest 1951;30:941-7.

27 Steel CL, Evans J, Smith MA. Physiological variations in circulating B cells: T cell ratio in man. Nature 1974;247:387-8.
28 Moorthy AV, Zimmerman AW. Human leucocyte responses to an endurance run. Eur J Applied Physiol 1978;38:271-6.

29 Ciuffetti G, Mercuri M, Palazzetti D, Lombardini R. Leukocyte rheology in recent stroke. Stroke 1988;19:122.

30 Engler R, Schmid-Schonbein GW, Pavelec RS. Leukocyte capillary plugging in myocardial ischemia and reperfusion in the dog. Am J Pathol 1983;111:98-111.

Requests for reprints to: Dr Giovanni Ciuffetti, Second Department of Internal Medicine, University of Perugia, Policlinico Monteluce, Perugia 06100, Italy. 